\title{
PEMUJAAN BARONG DI BALI DALAM PANDANGAN ANIMISME EDWARD BURNETT TYLOR
}

\author{
Oleh :
}

\author{
I Putu Ariyasa Darmawan
}

\begin{abstract}
ABSTRAK
Edward Burnett Tylor memandang agama sebagai keyakinan terhadap sesuatu yang spiritual. Agama tidak hanya sebagai sebuah teori, hapalan, atau sebuah kegiatan semata, namun setiap aktivitas agama memiliki sebuah makna spriritual. Pandangan E.B. Tylor sejalan dengan konsep agama Hindu di Bali, bahwa segala yang ada di alam semesta ini, memiliki sebuah roh yang membuat ia memiliki kekuatan seperti manusia.

Pemujaan terhadap Barong di Bali bukanlah memuja sebuah benda yang memiliki wujud seperti Barong, wujud tersebut dibuat hanya untuk menggambarkan Tuhan yang tak terbayangkan ke sebuah wujud yang bisa digambarkan.

Secara keseluruhan, pandangan Edward Burnett Tylor mempertegas keyakinan masyarakat Hindu di Bali tentang pemujaan terhadap Barong, bahwa ada suatu kekuatan yang menjiwai Barong sehingga ia mampu melindungi masyarakat.
\end{abstract}

\section{ABSTRACT}

Edward Burnett Tylor view religion as faith is something spiritual. Religion is not just a theory, memorize, or only an activity, but every religious activity has a spiritual meaning. Edward Burnett Tylor opinion same with Hinduism concept in Bali, that everything all in universe, have a spirit that makes it have such power as man.

The worship of Barong in Bali wasn't worship an object having such a shape an Barong, the entity was created only for ring out God unthinkable to a sort of entity.

On the whole, Edward Burnett Tylor opinion emphasize Hindu community confidence in Bali about veneration of Barong, that there is a force the soul a Barong, so that it able to protect people.

Keyword: Barong, Animism, Edward Burnett Tylor

\section{PENDAHULUAN}

Adanya keinginan manusia untuk mewujudkan Tuhan sebagai simbol atau lambangNya karena akal dan pikiran umat manusia sangat terbatas. Keterbatasan kemampuan manusia ini menyebabkan manusia mewujudkan Tuhan dalam berbagai manifestasi, seperti Dewa Dewi, Awatara, Lingga, dan di Bali dalam wujud Barong, Rangda, 
Arca, maupun Pratima. Konsep ini disebut dengan Saguna Brahman, yaitu salah satu jalan atau cara untuk menghayati dan meyakini Tuhan dalam berbagai aspek manifestasi-Nya, baik dalam manifestasi-Nya sebagai dewa-dewa atau sebagai Avatāra 'reinkarnasi Tuhan' (Donder, 2006: 234).

Keterbatasan pikiran manusia ini menyebabkan manusia, terutama umat Hindu di Bali menggunakan simbol dalam mewujudkan Tuhan. Bahasa simbol jauh melampaui pemakaian konsep-konsep abstrak untuk mengungkapkan pengalaman tentang Tuhan. Simbol adalah tanda yang mengungkapkan seseuatu yang tidak terungkap langsung, yang tidak langsung tertangkap secara indrawi. Simbol dalam arti sebenarnya adalah tanda yang bukan bukannya mewakilkan apa yang dimaksud, melainkan di dalamnya apa yang dimaksud hadir (Suseno, 2006: 191).

Keberadaan Barong dan Rangda hampir ada di setiap pura di Bali. Barong dan Rangda di Bali tidak hanya sebagai sebuah seni, tetapi lebih sebagai sebuah kekuatan yang mampu melindungi manusia dalam berbagai aktivitasnya. Benda-benda provan dapat berubah statusnya menjadi benda-benda sakral karena diperuntukkan untuk mewujudkan tujuan-tujuan suci (Donder 2007:291). Barong yang telah disucikan dan disakralkan tentu memiliki sebuah kekuatan yang mampu melindungi, mengikat, masyarakatnya. Keyakinan ini disebut dengan animisme, yaitu keyakinan akan adanya roh bahwa segala sesuatu di alam semesta ini didiami dan dikuasai oleh roh yang berbeda-beda pula (Titib, 2003: 28).
Animisme merupakan keyakinan akan realitas jiwa yang imanen di dalam dan yang meliputi segala sesuatu; manusia, hewan, batu karang, sungai, pohon, bumi, bulan, binatang, sebagai kekuatan penuntun (Bagus, 2005: 50-51). Umat Hindu meyakini segala yang ada di dunia ini pasti memiliki sebuah jiwa, entah jiwa yang baik atau yang kurang baik, sehingga dimplementasikan dalam sebuah konsep memanusiakan alam, seperti pelaksanaan Tumpek Landep untuk menyucikan jiwa dari benda besi, Tumpek Wariga untuk menyucikan jiwa tumbuhan, Tumpek Krulut untuk menyucikan jiwa gamelan, Tumpek Uye untuk menyucikan jiwa hewan, Tumpek Wayang untuk menyucikan wayang, dan Buda Cemeng Klawu atau Rambut Sedana untuk menyucikan uang.

\section{Edward Burnett Tylor (1832-1917)} mengungkapkan bahwa pada saat animisme diserap oleh berbagai suku, klan, dan peradaban, dia juga menyebar ke dalam setiap aspek kehidupan seharihari. Maka jika ada yang bertanya kenapa dalam hampir setiap kebudayaan dewa-dewa memiliki pribadi seperti layaknya manusia? jawabannya adalah karena mereka adalah roh-roh yang menyerupai jiwa-jiwa manusia. Ungkapan E.B. Tylor ini menarik untuk mengkaitkan pandangan animismenya dengan penggunaan Barong sakral di Bali.

\section{PEMBAHASAN}

\section{II.1 Barong di Bali}

Banyak definisi yang diberikan oleh para ahli dalam mendefinisikan Barong. Secara etimologi, kata Barong berasal dari bahasa 
Sanskerta yaitu $b(h)$ arwang yang di dalam bahasa Melayu atau bahasa Indonesia sejajar dengan kata beruang. Kata $b(h)$ arwang bersinonim dengan bahasa Belanda: Beer yang juga berarti binatang beruang. Jadi salah satu definisi Barong adalah binatang beruang (Segara, 2000:9). Definisi lain tentang Barong yaitu Barong berasal dari urat kata ba-ru-ang. Huruf u dan a berasimilasi menjadi o, sehingga $r u$ dan $a(n g)$ menjadi ro(ng) yang berarti dua. Kamus Besar Bahasa Indonesia menyebutkan bahwa Barong berarti tarian yang memakai kedok dan kelengkapan sebagai binatang buas (singa), dimainkan oleh dua orang (satu di depan di bagian kepala, dan satu di belakang di bagian ekor), dipertunjukkan dengan cerita Calonarang (Tim, 1991:95). Ensiklopedi Nasional Indonesia menjelaskan Barong berarti sebuah perangkat seni Bali, berupa selubang perwatakan atau baju topeng.

Dapat disimpulkan bahwa Barong adalah suatu kreasi budaya masyarakat yang terlahir dari filsafat Bānaspati Rāja dan mengambil wujud berdasarkan cerita yang berkaitan dengan Calonarang, Barong secara umum memiliki dua ruang dan mempunyai nilai religius ketika telah dihidupkan atau dipasupati.

Filsafat Barong menurut Lontar Kanda Pat Bhūta adalah Bānaspati Rāja, yaitu: Bānaspati Rāja, lahir dari telinga, warnanya kuning, suaranya $a h$, menjadi api yang kuning, diwujudkan sebagai Barong dan menjaga kayu besar atau hutang: kepah, kepuh, rangdu, dan lainlain. Sebagai makanannya boleh memakan orang yang menebang kayu atau yang naik pohon pada waktu-waktu terlarang oleh kecaping aksara atau padewasan (Bendesa K. Tonjaya dalam Segara, 2000:16-17).

Terdapat banyak jenis Barong di Bali, Titib (2003: 418-422) menjelaskan bahwa jenis Barong di Bali antara lain Barong Ket, Barong Bangkal, Barong Asu, Barong Macan, Barong Gajah, Barong Sampi, Barong Singa, Barong Landung, Barong Brutuk, Barong Blas-blasan, Barong Gagombrangan, Barong sae, Barong Jaran, Barong Menjangan, dan Barong Dawang-Dawang. Diantara semua Barong yang disebutkan di atas, Barong Ket merupakan jenis Barong yang paling banyak terdapat di setiap desa di Bali.

Dalam perspektif teologi Saguna Brahman Tuhan dipandang sebagai Ayah, Ibu, dan Datuk alam semesta beserta isinya. Dalam fungsi dan kedudukan Tuhan sebagai Ayah dan Ibu bagi umat manusia, maka Tuhan dapat dipandang sebagai asal-mula adanya masyarakat (Donder,2009:23). Ketika masyarakat memandang Tuhan dalam manifestasi Beliau sebagai Barong merupakan Ayah, dan semua Rangda yang ada di Pura merupakan Ibu, maka masyarakat menghormati dan melayani semua simbol suci tersebut layaknya melayani orang tua sendiri.

Keberadaan Barong tidak bisa terlepas dari sosok Rangda, hal ini menunjukkan adanya konsep Rwa Bhineda, yaitu dua hal yang berbeda namun tidak bisa dipisahkan satu dengan yang lainnya. Rwa bhineda yang muncul adalah simbol Purusa dan Pradhana, bahwa Barong sebagai simbol Purusa atau laki-laki yang sering diidentikkan 
dengan Dewa Siwa, dan Rangda sebagai simbol Pradhana atau perempuan yang diidentikkan dengan Dewi Durga.

\section{Keberadaan Barong dan Rangda} yang ada di sebuah Pura tentu berbeda dengan Barong dan Rangda yang dipertunjukkan bagi wisatawan. Barong yang ada di Pura yang telah disucikan memiliki jiwa yang mampu melindungi masyarakat. Jiwa tersebut diyakini bukan jiwa yang sembarangan dan kotor, Ia adalah jiwa yang bersih dan suci. Diyakini merupakan sebuah percikan Ida Sang Hyang Widhi Wasa dalam manifestasi Beliau sebagai Dewa Siwa kemudian turun memasuki Barong, dan manifestasi sebagai Dewi Durgā turun memasuki Rangda. Dengan adanya paham animisme ini akan tercipta hubungan yang harmonis antara manusia dengan Tuhan dan seluruh ciptaan Beliau. Dengan menganggap semua ciptaan Tuhan memiliki jiwa, termasuk sebuah simbol suci, maka akan terbentuk suatu sikap yang luhur dalam diri manusia sehingga dapat menghormati semua ciptaan Tuhan.

Barong Ket timbul selaku gejala seni (dengan segala predikatnya: magis, rituil, religius, folk, folk feodal dan sebagainya) hanyalah mungkin dari sebuah "social complex ideas", gagasan masyarakat primitif kompleks, gejalagejala kehidupan memang masih mungkin ditelusuri secara terpisah tanpa memandang suatu gap (Tim, 1975/1976:17). Sesuai penelitian Tim Proyek sasana Budaya Bali tersebut, dapat ditarik sebuah hasil bahwa sejak timbulnya Barong sudah memiliki unsur seni dan magis. Ide pembuatan sebuah Barong awalnya pada jaman dahulu kala adalah untuk mendapatkan sebuah perlindungan dalam hal religius, karenanya Barong disthanakan pada sebuah Pura dan hanya bisa dilihat pada saat piodalan di Pura tersebut.

\section{II.2 Pemujaan Barong Dalam Pandangan Ani- misme Edward Burnett Tylor}

Edward Burnett Tylor (1832-1917) adalah seorang pria otodidak Inggris yang tidak pernah mendapatkan pendidikan universitas, namun dengan petualangan dan studi independennya, sampai kepada teori animisme, sebuah teori yang menurutnya adalah kunci untuk memahami asal usul agama (Pals, 2012:30).

Edward Burnett Tylor mengawali pandangannya dari definisi agama, bahwa kita tidak akan bisa menjelaskan sesuatu tanpa mengetahui apa sebenarnya hakekat sesuatu tersebut, sehingga pertama-tama kita harus mendefinisikan agama terlebih dahulu, yaitu agama sebagai keyakinan terhadap sesuatu yang spiritual (Pals, 2012:41). Pendapat Tylor ini mempertegas bahwa agama tidak hanya sebagai sebuah teori, hapalan, atau sebuah kegiatan semata, namun setiap aktivitas agama memiliki sebuah makna spriritual yang tidak kelihatan, yang hanya bisa dirasakan hasil dan manfaatnya.

Satu-satunya karakteristik yang dimiliki setiap agama, besar maupun kecil, agama purba atau modern, adalah keyakinan terhadap rohroh yang berpikir, berperilaku dan berperasaan seperti manusia (Pals, 2012:41). Pernyataan ini 
dipertegas bahwa esensi setiap agama, seperti juga mitologi, adalah animisme. Pandangan E.B. Tylor sejalan dengan konsep agama Hindu di Bali, bahwa segala yang ada di alam semesta ini, memiliki sebuah roh yang membuat ia memiliki kekuatan seperti manusia. Perwujudan Barong dan Rangda diyakini memiliki kekuatan yang melebihi kekuatan manusia, seperti memiliki sifat melindungi manusia.

Animisme merupakan suatu paham bahwa alam ini atau semua benda memiliki roh atau jiwa (Maulana dalam Donder, 2006:138). Animisme juga menjelaskan kenapa benda-benda dan pernik-pernik yang disakralkan begitu penting bagi masyarakat primitif. Masyarakat ini bukanlah 'penyembah berhala', mereka tidak menyembah tongkat atau bebatuan, tetapi menyembah 'anima' yang ada di dalamnya, roh yang memberikan kekuatan dan kehidupan kayu tongkat atau substansi bebatuan tersebut (Pals, 2012:43). Ungkapan tersebut mematahkan pandangan orang tentang agama Hindu yang keliru terkait pemujaan benda-benda sakral.

Pemujaan terhadap Barong di Bali bukanlah memuja sebuah benda yang memiliki wujud seperti Barong, baik berupa Barong Ket, Barong Bangkal, Barong Macan, Barong Brutuk, ataupun Barong Landung, bahkan memuja sesuatu yang menyeramkan seperti Rangda yang selalu mendampingi Barong. Pemikiran umat Hindu dalam sebuah pemujaan, jauh melampaui apa yang terlihat secara kasat mata. Umat Hindu tidak memuja wujud tersebut, wujud tersebut dibuat hanya untuk menggambarkan Tuhan yang tak terbayangkan ke sebuah wujud yang bisa digambarkan.
Membayangkan Tuhan yang tak terbayangkan ke sebuah wujud yang bisa digambarkan dalam pemujaan agama Hindu bukanlah sebuah hayalan belaka. Semua uaha itu bersifat rasional, dan bisa dibuktikan, seperti adanya tanda-tanda alam atau kemunculan sesuatu yang tidak bisa dipikirkan. Tanda-tanda tersebut tentu bersifat melindungi umat dan menunjukkan kuasa Tuhan Yang Maha Esa, yang muncul dari kekuatan yang dipuja. Seperti mitos-mitos mereka, pengajaran agama muncul dari usaha rasional untuk menjelaskan cara kerja alam. Dan dari perspektif ini, semua sudah jelas, bahwa sebagaimana roh menggerakkan seorang manusia, maka spirit pun telah menggerakkan alam semesta (Pals, 2012:43).

Agama Hindu mengajarkan untuk selalu menjaga keharmonisan dengan alam semesta. Manusia akan bahagia ketika alam mampu memberikan apa yang manusia inginkan, demikian juga sebaliknya. Keharmonisan ini dilaksanakan melalui kegiatan memanusiakan alam, apa yang ada di alam ada dalam diri, semua yang ada memiliki jiwa. Seniman akan memperlakukan perlengakapan seninya seolah-olah memiliki jiwa yang membuat tampilan atau pertunjukan seninya memiliki aura yang berbeda, lebih berwibawa. Masyarakat yang memuja Barong sakral di sebuah pura, mempercayai jiwa yang berada dalam Barong tersebut memiliki karakter seperti manusia.

Tylor lebih lanjut berargumen bahwa arti penting teori animistik ini ketika menjelaskan masyarakat primitif akan terlihat dari varianvarian kepercayaan dan adat istiadat purba yang dijelaskannya. Pada saat animisme diserap oleh 
berbagai suku, klan, dan peradaban, dia juga menyebar ke dalam setiap aspek kehidupan seharihari. Maka jika ada yang bertanya kenapa dalam hampir setiap kebudayaan dewa-dewa memiliki pribadi seperti layaknya manusia? jawabannya adalah karena mereka adalah roh-roh yang menyerupai jiwa-jiwa manusia (Pals, 2012:44).

\section{PENUTUP}

Secara keseluruhan, pandangan Edward Burnett Tylor mempertegas keyakinan masyarakat Hindu di Bali tentang pemujaan terhadap Barong, bahwa ada suatu kekuatan yang menjiwai Barong sehingga ia mampu melindungi masyarakat. Masyarakat tidak memuja wujud tersebut, wujud tersebut dibuat hanya untuk menggambarkan Tuhan yang tak terbayangkan ke sebuah wujud yang bisa digambarkan.

Animisme merupakan keyakinan akan realitas jiwa yang imanen di dalam dan yang meliputi segala sesuatu; manusia, hewan, batu karang, sungai, pohon, bumi, bulan, binatang, sebagai kekuatan penuntun. Animisme merupakan suatu paham bahwa alam ini atau semua benda memiliki roh atau jiwa.

Edward Burnett Tylor memandang agama sebagai keyakinan terhadap sesuatu yang spiritual. Agama tidak hanya sebagai sebuah teori, hapalan, atau sebuah kegiatan semata, namun setiap aktivitas agama memiliki sebuah makna spriritual. Karakteristik yang dimiliki setiap agama adalah keyakinan terhadap roh-roh yang berpikir, berperilaku dan berperasaan seperti manusia. Pandangan E.B. Tylor sejalan dengan konsep agama Hindu di Bali, bahwa segala yang ada di alam semesta ini, memiliki sebuah roh yang membuat ia memiliki kekuatan seperti manusia.

Pemujaan terhadap Barong di Balibukanlah memuja sebuah benda yang memiliki wujud seperti Barong, wujud tersebut dibuat hanya untuk menggambarkan Tuhan yang tak terbayangkan ke sebuah wujud yang bisa digambarkan.

\section{DAFTAR PUSTAKA}

Bagus, Lorens. 2005. Kamus Filsafat. Jakarta : Gramedia

Donder, I Ketut. 2006. Brahmavidya : Teologi Kasih Semesta Kritik Terhadap Epistemologi Teologi, Klaim Kebenaran, Program Misi, Komparasi Teologi, Dan Konversi. Surabaya : Paramita

Donder, I Ketut. 2007. Viratvidya Kosmologi Hindu Penciptaan, Pemeliharaan, dan Peleburan Serta Penciptaan Kembali Alam Semesta. Surabaya : Paramita

Pals, Daniel L. 2012. Seven Theories Of Religion. (Inyiak Ridwan Musir dan M. Syukri, Pentj). Jakarta : IRCiSoD

Segara, Nyoman Yoga. 2000. Mengenal Barong Dan Rangda. Surabaya : Paramita

Suseno, Franz Magnis. 2006. Menalar Tuhan. Yogyakarta : Kanisius 
Tim Penyusun. 1975/1976. Barong Di Bali Ditinjau Dari Segi Rituil dan Perkembangannya Sebagai Seni Pertunjukan. Denpasar : Proyek Sasana Budaya Bali.

Tim Penyusun. 1991. Kamus Besar Bahasa Indonesia Jilid Kedua. Jakarta : Departemen Pendidikan dan Kebudayaan

Titib, I Made. 2003. Teologi \& Simbol-Simbol Dalam Agama Hindu. Surabaya : Paramita 